\author{
MICHAŁ NOWICKI* \\ Wydział Studiów Edukacyjnych \\ Uniwersytet im. Adama Mickiewicza w Poznaniu \\ ORCID:0000-0001-6147-9295
}

\title{
KSZTAŁCENIE PRZYSZŁYCH SENATORÓW W AKADEMII LUBRAŃSKIEGO W XVII I XVIII W.
}

\author{
Education of future senators at the Lubrański Academy \\ in the $17^{\text {th }}$ and $18^{\text {th }}$ centuries
}

\begin{abstract}
The purpose of this study is to show the educational situation of the youth of magnate origin, especially the sons of Senators and future senior state officials at the Lubrański Academy in 1613-1780. To this end, the educational needs of this social group as well as the educational offer of the Poznań school are analyzed, using various source materials, to a large extent panegyric literature, showing educational methods, and pointing to transformations occurring during the Enlightenment.
\end{abstract}

Keywords: Lubrański Academy, old Polish education, history of education, Senators, social elites

\begin{abstract}
Abstrakt
Zadaniem niniejszego opracowania jest ukazanie sytuacji edukacyjnej młodzieży magnackiego pochodzenia, zwłaszcza synów senatorów i przyszłych najwyższych urzędników państwowych w Akademii Lubrańskiego w latach 1613-1780. W tym celu analizie poddano potrzeby edukacyjne tej grupy społecznej oraz ofertę edukacyjną poznańskiej szkoły, wykorzystując różnorodne materiały źródłowe, w dużym stopniu literaturę panegiryczną, ukazując metody wychowawcze i wskazując na zachodzące w okresie oświeceniowym przemiany.
\end{abstract}

Słowa kluczowe: Akademia Lubrańskiego, szkolnictwo staropolskie, historia wychowania, senatorowie, elity społeczne

\footnotetext{
Michał Nowicki - adiunkt w Zakładzie Historii Wychowania UAM, prowadzi badania naukowe z zakresu historii wychowania staropolskiego, zwłaszcza w odniesieniu do szkolnictwa, a także dziejów edukacji religijno-filozoficznej w szkołach filozoficznych Indii oraz Europy Zachodniej.
} 
Akademia Lubrańskiego, jedna z najznaczniejszych szkół średnich I Rzeczypospolitej, dzięki sprofilowaniu programu kształcenia na potrzeby szlachty, przyciągała do swoich murów młodzież przede wszystkim z Wielkopolski, ale były wśród jej uczniów osoby także z odleglejszych miejsc, w tym z ośrodków zagranicznych. Za cel stawiała sobie przygotowanie uczniów do życia publicznego, dostosowanego do ówczesnych realiów polityczno-kulturalnych. Zawierało się w tym kształcenie dla czynnego i biernego uczestniczenia w życiu literackim, z dużym naciskiem na retorykę, ale też merytoryczne obeznanie uczniów w zakresie niezbędnym do funkcjonowania w rzeczywistości społeczno-gospodarczej, wraz z pożądanym przez niektórych kursem prawa cywilnego i kanonicznego. Wszystko $\mathrm{z}$ umiarkowaną obecnością religii. Biorąc to pod uwagę, nie dziwi duże zainteresowanie tą ofertą edukacyjną szlachty, pomimo obecności w Poznaniu konkurencyjnej, i największej w ówczesnej Polsce, szkoły jezuickiej. Szlachty przede wszystkim średniej, ale reprezentowanej też przez magnaterię. Zadaniem niniejszego artykułu będzie próba ukazania sytuacji edukacyjnej uczniów magnackiego pochodzenia, synów senatorów i przyszłych najwyższych urzędników państwowych w Akademii Lubrańskiego po jej odnowieniu w 1613 r. Przedmiotem szczególnej uwagi będzie sposób ich traktowania w szkole oraz dostosowanie programu nauczania do ich potrzeb.

Ażeby możliwe było przeanalizowanie tego zagadnienia, trzeba najpierw wskazać na potrzeby edukacyjne magnaterii w omawianym przedziale czasowym. Przede wszystkim należy podkreślić, że w okresie staropolskim nie wyobrażano sobie funkcjonowania w społeczeństwie bez uzyskania odpowiedniego wykształcenia. I chociaż nie istniał wówczas przymus szkolny, to można mówić o swoistym „,przymusie towarzyskim”" Potrzeby edukacyjne zasadniczo zmieniały się wraz z mijającym czasem, wynikały z polskiego ustroju społecznego i wiązały się z aktualnymi trendami europejskimi. Można jednak wskazać na trzy stałe elementy - przygotowanie do służby publicznej dla państwa, do życia kulturalnego oraz wychowanie w pobożności.

Realizacja pierwszego postulatu wymagała przede wszystkim znajomości funkcjonowania państwa, jego pozycji na arenie międzynarodowej, urzędów, skomplikowanych zależności genealogicznych, ale też i heraldyki, w połączeniu z historią państwa, władców i poszczególnych rodów. Duże znaczenie miała znajomość prawa polskiego, przynajmniej na elementarnym poziomie (powszechne było zdobywanie wiedzy prawniczej w praktyce w palestrze ${ }^{2}$ ). Ważne było także posiadanie orientacji w ówczesnym życiu gospodarczym. Wszystkie te elementy przewyższała jednak potrzeba zdobycia umiejętności językowych ${ }^{3}$. Od XVII do poł. XVIII w. szlachta w życiu politycznym posługiwała się specyficzną mieszanką języków łacińskiego i polskiego, w drugiej poł. XVIII w. ustępującą miejsca językowi polskiemu, co zostało zapoczątkowane na dworze królewskim Stanisława Augusta

1 D. Żołądź, Ideały edukacyjne doby staropolskiej. Stanowe modele i potrzeby edukacyjne szesnastego i siedemnastego wieku, Warszawa-Poznań 1990, s. 25.

2 J. Kitowicz, Opis obyczajów za panowania Augusta III, Warszawa 1985, s. 108 i nn. Por. B. Sobieraj, „Dla edukacyi, lub też dla dalszej professyi promocyi" - uwagi o edukacji młodzieży szlacheckiej w palestrze w XVIII wieku, w: Spoleczne i kulturowe uwarunkowania edukacji Rzeczypospolitej XVI-XVIII wieku. Materiaty z badań, część pierwsza, red. K. Puchowski, wstęp i oprac. J. Orzeł, Warszawa 2017, s. 117-134; idem, Z problematyki nauczania prawa ojczystego i narodów w pijarskim Collegium Nobilium w Warszawie, w: Społeczne i kulturowe uwarunkowania edukacji Rzeczypospolitej XVI-XVIII wieku. Materiały z badań, część druga, red. K. Puchowski, wstęp i oprac. J. Orzeł, Warszawa 2018, s. 51-60.

3 Zob. na ten temat: M. Cieśla, Dzieje nauki języków obcych w zarysie, Warszawa 1974. 
Poniatowskiego ${ }^{4}$. W pierwszej poł. XVII w. popularny stał się w kołach senatorskich także język niemiecki, w dużym stopniu ze względu na fakt jego używania na dworze królewskim; w drugiej połowie zastąpił go język francuski. Obok nich w stuleciu tym królowie chętnie posługiwali się jeszcze językiem włoskim, stąd też i on musiał dołączyć do kanonu wykształcenia magnackiego ${ }^{5}$.

Drugi postulat natomiast w dużym stopniu stanowił uzupełnienie pierwszego, a związany był z życiem kulturalnym, w zasadzie koncentrującym się na twórczości literackiej i umiejętności jej publicznej prezentacji. Od wykształconego człowieka wymagano z jednej strony umiejętności odczytywania kodu kulturowego, zawartego w rozmaitych formach literackich, z drugiej natomiast czynnego uczestniczenia w życiu literackim - tworzenia utworów na różne okoliczności, od mów sejmowych począwszy, skończywszy na epitafiach czy epitalamiach. Wiadomo przecież, że życie szlacheckie lubowało się w uroczystych, bogatych w ornamentykę słowną przemówieniach i panegirykach. Umiejętności te były niezbędne w życiu politycznym magnaterii, ale także i prywatnym.

Od przyszłego senatora oczekiwano więcej niż od szlachty średniej. Do tych wymagań zaliczyć trzeba obycie w świecie, wiedzę o aktualnych trendach w polityce, gospodarce, filozofii (to zwłaszcza w wieku XVIII), ale też i znajomość konkretnych, prominentnych ludzi. Polscy magnaci chętnie zdobywali wiedzę z zakresu architektury, zachodnioeuropejskiej sztuki wojennej (z czym wiązała się konieczność zdobycia w pewnym stopniu wiedzy matematyczno-przyrodniczej), fechtunku, woltyżerki, ale też i tańca.

Szeroki zakres tych potrzeb sprawił, że edukacja synów magnackich nie mogła ograniczyć się tylko do szkoły, stąd też stała się kilkuetapowa i angażowała znaczące środki i siły. Szacuje się, że tylko około jedną trzecią synów magnackich wysyłano na naukę do szkół krajowych ${ }^{6}$. Znacząca część uczyła się w domach, pierwsze nauki pobierali tam także późniejsi uczniowie szkół. Dalszym etapem często były studia uniwersyteckie w kraju, przy czym należy pamiętać, że do ich podjęcia nie było trzeba ukończyć szkoły średniej, ale też i o tym, że nie wszyscy byli zainteresowani tym elementem. Zwłaszcza, że np. Akademia Krakowska uchodziła za uczelnię plebejską, a oferowane przez nią wykształcenie czy stopnie nie były potrzebne do kariery publicznej. Zdecydowanie większą popularnością cieszyły się podróże edukacyjne, które uważane były za zwieńczenie edukacji młodego magnata. Co prawda zdarzały się głosy krytykujące praktykę wyjazdów zagranicznych, wskazujące na ich bezzasadność, a zwłaszcza zagrożenia z nimi związane; głosy te były jednak sporadyczne. Po podróżującej młodzieży spodziewano się zdobycia przede wszystkim ogłady, ogólnego wykształcenia i przydatnych umiejętności, obeznania w ówczesnym życiu towarzyskim, obowiązujących trendach. Raczej na drugim miejscu stawiano kształcenie uniwersyteckie na zachodnich uczelniach ${ }^{7}$. To, zważywszy na praktykę zmiany miejsc pobytu, i tak nie

J. Axer, Kultura polska z punktu widzenia mechanizmów recepcji tradycji antycznej. Prolegomena do syntezy, w: Humanistyczne modele kultury nowożytnej wobec dziedzictwa starożytnego, red. M. Prejs, Warszawa 2010, s. 52,60 .

5 W. Czapliński, J. Długosz, Życie codzienne magnaterii polskiej w XVII wieku, Warszawa 1982, s. 25.

6 Ibidem, s. 26.

7 Por. poszczególne instrukcje rodzicielskie wraz z komentarzami: Ojcowskie synom przestrogi: instrukcje rodzicielskie (XVI-XVII w.), red. D. Żołądź-Strzelczyk, M.E. Kowalczyk, Wrocław 2017; Przestrogi i nauki dla dzieci: instrukcje rodzicielskie (XVIII w.), red. D. Żołądź-Strzelczyk, M.E. Kowalczyk, Wrocław 2017. 
mogło być gruntowne (pobyt w jednym miejscu raczej nie trwał dłużej niż rok czy dwa lata), chociaż oczywiście zdarzały się wyjątki.

Kiedy patrzy się na zagadnienie kształcenia przyszłych senatorów z tej perspektywy, oczywiste się staje, że Akademia Lubrańskiego mogła sprostać ich oczekiwaniom tylko w ograniczonym zakresie. Czy zatem przyciągała do swoich murów przyszłych senatorów? Chociaż nie są dzisiaj znane listy uczniów tej szkoły, to dzięki zachowanym starodrukom, publikującym twórczość uczniowską, wpisom w aktach kapitulnych czy księdze konwokacji można odpowiedzieć na to pytanie w sposób twierdzący i przywołać, tytułem przykładu, kilka znaczących nazwisk. Do grona uczniów Lubranscianum zaliczyć należy Krzysztofa Opalińskiego, który piastował m.in. urzędy wojewody poznańskiego, marszałka Trybunału Głównego Koronnego i starosty śremskiego; Łukasza Opalińskiego - kasztelana poznańskiego, marszałka nadwornego, a następnie wielkiego koronnego, wojewody rawskiego itd.; Wojciecha Tolibowskiego - biskupa poznańskiego; Krzysztofa Grzymułtowskiego - kasztelana i wojewody poznańskiego, starosty ujsko-pilskiego. Jeśli do tego dodać, że z poznańską uczelnią in Summo związane były fundacjami rodziny Rozdrażewskich (herbu Doliwa), Szołdrskich (h. Łodzia) czy Radomickich (h. Kotwicz), to okaże się, że uczniów tych musiało być w omawianym okresie całkiem dużo. A nazwiska te nie zamykają listy magnackich wychowanków Akademii Lubrańskiego; będą wśród nich także Potoccy (h. Pilawa) czy Działyńscy (h. Ogończyk $)^{8}$. Interesujący jest także fakt wielopokoleniowego przywiązania do Akademii Lubrańskiego, który musi świadczyć o jej dobrej sławie i zaspokajaniu potrzeb tych rodów, zwłaszcza, jeśli weźmie się pod uwagę fakt funkcjonowania po drugiej stronie Warty największego w Koronie kolegium jezuickiego, kształcącego w tym czasie ponad tysiąc uczniów.

Kiedy się to uwzględni, a dodatkowo zna ówczesną sytuację w szkolnictwie, nie powinna dziwić szczególna dbałość o dobre relacje szkoły z rodami magnackimi, przybierająca niekiedy niebezpieczną wychowawczo postać wywyższania ich pozycji społecznej, a także faworyzowania ich dzieci, pozostających pod opieką Akademii. Zachowała się niezliczona ilość panegiryków autorstwa profesorów Lubranscianum, wychwalających cnoty wybranych osób czy znamienitych rodów (nie było to zjawisko wyjątkowe, ale powszechne). Można na to zagadnienie spojrzeć $\mathrm{z}$ dwóch perspektyw. Najczęściej $\mathrm{w}$ historiografii podkreśla się zgubny wpływ takich praktyk na wychowanie młodzieży ${ }^{9}$, zwłaszcza jeśli weźmie się pod uwagę kontekst historyczny, ukazujący dość powszechne zepsucie moralne wśród szlachty. Czy są ku temu podstawy? Rzut oka na wybrane fragmenty tej „literatury” może dać pewne wyobrażenie:

„Fortuna haec comparata labore, ex reverentia in Regnantes, ex amore in Patriam, ex meritis in Rem-publicam collecta, etiam in aliam nequit, tantum in SZOLDRSCIANAM transferri DOMUM. [...] Successivum in SZOLDRSCIIS crede honorem; gesserunt omnes dignitatum titulos, et gerunt: floruerunt sub violis, et florent: rubuerunt sub

\footnotetext{
8 Zob. M. Nowicki, Akademia Lubrańskiego: organizacja szkoły i działalność wychowawcza, Warszawa 2015, s. 202 i nn.

9 Odrębnym zagadnieniem jest wpływ panegiryku na wychowanie estetyczne, któremu w literaturze też poświęcono dużo uwagi. W kontekście szkolnym zob. T. Bieńkowski, Panegiryk a życie literackie w Polsce XVI i XVII wieku, w: Z dziejów życia literackiego w Polsce XVI i XVII w., red. H. Dziechcińska, Wrocław 1980, s. 183 i nn.; por. K. Dmitruk, Problemy publiczności literackiej w dawnej Polsce, w: Publiczność literacka i teatralna w dawnej Polsce, red. H. Dziechcińska, Warszawa-Łódź 1985, s. 9-10, 37.
} 
Rosis, et rubent: ornarunt utramque Purpuram Praesules et Purpurati Patres, et ornant: illustrarunt Sagum et Togam Senatores, et adhuc illustrare non cessant"10.

„Fastigia dignitatum, titulorum vertices, moles augustae, honorumque juga ipsum tangentia Olympum, Tuae se hodie ILLUSTRISSIME GENERALIS inclinant magnitudini, quae ex meritis crescit, ex animo venit, ipsis Intelligentiis vicina, quia mentium Apex et Culmen"11.

Można jednak też pokusić się o głębszą analizę treści tych panegiryków. Pozwala ona ujrzeć dość szeroki wachlarz wartości wychowawczych, zawartych w takich tekstach. Przede wszystkim budują one obraz idealnego męża stanu, wzoru, który bez zastanowienia warto naśladować. Zważywszy na arystokratyczne przekonanie o dziedziczeniu cech charakteru, praktyka panegiryzowania mogła mieć stymulujący wpływ na młodzież. Przywoływanie wielkich czynów przodków musiało pobudzać wyobraźnię uczniów i chęć do naśladowania tych dokonań. Pamiętać trzeba, że o wartości „polskiego dworzanina” decydowało nie tylko urodzenie, ale to, czy dana osoba mogła dorównać czynom przodków, a nawet ich przerosnąć:

„Ten dworzanin, którego ja tu formować mam, chcę naprzód, aby się w ślacheckim zacnym domu urodził, abowiem nie tak sromotna rzecz jest nieślachcicewi nie czynić spraw poczciwych, jako ślachcicewi, który jeśli namniej zstąpi z tej drogi, którą szli przodkowie jego, zostawi zmazę na domu na swym a nie telko nie przybawi nic, ale straci i to, co było nabyte; gdyż ślachectwo jest jako rozpalona pochodnia, która objaśnia i kładzie przed oczy dobre i złe człowiecze sprawy i pobudza, zapala ku cnocie tak bojaźnią niesławy, jako też nadzieją czci a chwały. Więc iż ta pochodnia nie rozświeca uczynków podłych ludzi, przeto nie mają oni pobidki do cnoty ani bojaźni niesławy, i owszem, zda się im, iż nie powinni starać się o to, aby w czym przodki swe przeszli; a ślachcicewi nieprzystojna rzecz się widzi nie przyść acz nic ku temu kresu, ku któremu przyszedł jego przodek" $" 12$.

Podkreślenia wymaga fakt, że w panegirykach tworzonych w murach Akademii Lubrańskiego wychwalano przede wszystkim wartości patriotyczne, zwłaszcza oddanie ojczyźnie. Można to dostrzec w przywołanych wyżej przykładach, które bynajmniej nie wyczerpują możliwości egzemplifikacyjnych. Warto przywołać krótki utwór kasztelanica poznańskiego, ucznia szkoły gramatyki Akademii, Feliksa Radomickiego, stawiający ród Tarłowskich na pozycji gwaranta bezpieczeństwa ojczyzny:

„Pacem consignant affixa Penatibus Arma,

Hanc fundat Lechiae, TARŁOVIANA Domus.

Secure Patriam servat, tutatur et Aras,

Divinum in terris ASCIA robur habet"13.

W takim tonie też utrzymana jest dalsza część utworu autorstwa profesora Józefa Dzianottiego, jak i inny, dedykowany Piotrowi Tarło, biskupowi-elektowi poznańskiemu, rok

\footnotetext{
10 A. Lipiewicz, Jason in Colchide Aurei Velleris [...], Posnaniae 1746, f. Av.

11 Ibidem, f. CV.

12 Ł. Górnicki, Dworzanin polski, w: Źródła do dziejów wychowania i myśli pedagogicznej, red. S. Wołoszyn, Kielce 1995, t. 1, s. 255.

13 J.J. Dzianotti, Securitas ecclesiae et patriae avita ascia ..., Posnaniae 1721, na odwr. k. tyt.
} 
wcześniej. Tutaj też, z wiersza burgrabicza poznańskiego Wojciecha Arcemberskiego płynie wiedza, że ród ten miał otrzymać swój herb - topór - od bogini Minerwy, by służyć narodowi lechickiemu (,ASCIA TARŁONUM profert tot datque Minervas / Quot servat Lechicos haec DOMUS Alma Joves"'14). Nawet przy okazji ingresu biskupa na Katedrę poznańską podkreślono korzyści z tego faktu dla ojczyzny (wskazuje zresztą na to sam tytuł utworu biskup miał według niego stanowić zabezpieczenie dla Kościoła i ojczyzny), zwłaszcza $\mathrm{z}$ uwagi na jego cnoty, zawsze oddane służbie sprawom publicznym ${ }^{15}$.

Pięknie opisywał te cnoty w kilku panegirykach także uczeń Akademii Lubrańskiego, Hieronim Hincza. W epitafium po śmierci Jana Czarnkowskiego, kasztelana międzyrzeckiego, podkreślał, w jak doskonały sposób wykorzystał swoje wykształcenie dla dobra Rzeczypospolitej („Oddał się Pospolitej rzeczy na posługi”), nie pozostając tym samym dłużnym „wiekopomnym czynom” swoich przodków, broniących granic kraju przed „dziczą Bisurmańską" i innymi nieprzyjaciółmi. Miał bowiem Czarnkowski, podczas swojego pobytu nad „bystrym Renem”, oddać się „gromadzeniu hojnych nauk wyzwolonych sprzętów” i rozwijaniu rozumu, a potem wspierać króla w wojnie morskiej przeciwko Szwedom ${ }^{16}$. W innym natomiast tekście sławił waleczność i męstwo rodu Gnińskich, którzy, jak dowodził jego szkolny kolega, Maciej Baranowski, mieli uzyskać swój klejnot herbowy dzięki wsparciu Marsa na polu bitwy ${ }^{17}$. Warto odnotować, że takich przykładów jest przynajmniej jeszcze kilkadziesiąt...

O wartościach cenionych w Akademii przekonać może panegiryk Antoniego Piątkowskiego, napisany z okazji pogrzebu jednego z uczniów szkoły poetyki, Andrzeja Działyńskiego:
„Wyczytać w ANDRZEIU Dziecięciu
Tym, mogł każdy, iak prędkość dowcipna w pojęciu
Szkolney pracy; rozumu bystrość niezwyczayna,
Ktora Lubranskim Muzom, bywała nie tayna.
Obrot konceptu prętki, bez wszego myślenia,
Wszystko zrozumiec, co iest uszom do słyszenia [...]
Układny w obyczaiach, lotny szkolnym piorem,
Tak że Synow Pallady, publicznym był wzorem;
Mowił byś ze zdroy cały, Parnassowey gory
Spełnił"18.

Interesującym przykładem jest też utwór dedykowany Teodorowi Koźmińskiemu, synowi wojewody kaliskiego oraz kasztelana kaliskiego i poznańskiego Macieja Koźmińskiego (herbu Poraj), który w tym czasie najprawdopodobniej był albo uczniem szkoły, albo już jej absolwentem. Autor sławi tutaj wprost liczne zalety mecenasa, podkreślając te, które są związane z mądrością, sprawiedliwością, elokwencją ${ }^{19}$.

\footnotetext{
14 Idem, Corona triumphalis militantis ecclesiae..., Posnaniae 1720, na odwr. k. tyt.

15 Idem, Securitas ecclesiae et patriae..., f. Av, A2.

16 H. Hincza, Stopnie do sławy..., Poznań 1619, f. B-B2.

17 Idem, Lubrański wskrzeszony, z drukarni Jana Wolraba 1618, na odwr. k. tyt.; A2.

18 A. Piątkowski, Niezamierzone strzały Działyńskich..., Poznań 1708, f. Cv.

19 A.F. Dunin, Corona tribus caelicolis..., Posnaniae 1755.
} 
Obok niewątpliwej wartości wychowawczej płynącej z podkreślania pozytywnych cech charakteru, dodatkowym atutem lektury panegiryków jest wykorzystywanie licznych odniesień erudycyjnych, mogących stanowić bodziec do indywidualnych studiów. Ówczesna kultura szlachecka wymagała bowiem znajomości rozmaitych kontekstów historycznych, historiograficznych i literackich. Te zaś często zamieszczane były w znaczących ilościach w jednym nawet zdaniu:

„Ita preaclarissimus illo dux Atheniensium, idemque totius Graeciae fulmen Pericles, Anaxagorae lucernam, superfuso liber alitatis suae oleo illustrabat; ita Pyrrhus Epirotarum Rex, secundus ab Alexadro Magno, ut Annibali visum est, Imperator, Cyneam suum, numerosissimis exercitibus ob singularem literarum, et sapientiae opinionem praeferebat" ${ }^{\prime 20}$.

Inną korzyścią, płynącą z przygotowywania takich tekstów i ich lektury, ważną dla magnaterii, była znajomość skomplikowanych koligacji rodzinnych ówczesnej szlachty, pieczołowicie rozpracowywanych w takich utworach, heraldyki czy urzędów. Zdarzały się w historii Lubranscianum także panegiryki wyjątkowe, nawołujące do lektury klasyków filozofii i historiografii ${ }^{21}$ czy przepełnione treściami z zakresu fizyki:

„Et spectata entitate rei, non dubitans me ex mente Vestra loqui: una Vobiscum assero: quod acta, actione, Munia, \& Officia Literati Hominis; formaliter entitative, (abstracte scilicet \& independenter ab accidentali, extrinseco ac minus principaliter exigito charactere) sumpta omnia sunt pure spiritualia. Tum quod nullis externis percipiuntur sensibus; non palpantur enim manibus, sicut arbores, lapides, aliaque materialia solida; non cernuntur oculis: quia nullum in se recipiunt materialem externum colorem Physicum; non resonant per se (nisi auxiliante ac subveniente instrumento gutture, \& labiis) tremore suo in auribus, quemadmodum sonus ex collisione duorum solidorum corporum causatus, per reverberationem intractabilis, \& delicati aeris stridens, continuatus ac reflexus" 22 .

Należy zauważyć wreszcie, że profesorowie Akademii Lubrańskiego poprzez panegiryki wpływali na wychowanie magnatów także poza murami szkoły i po zakończeniu edukacji. Znane są utwory dedykowane powracającym z podróży edukacyjnych młodzieńcom, prawdopodobnie będącym wcześniej uczniami Lubranscianum ${ }^{23}$.

Uczniowie należący do znamienitych rodów musieli czuć się wyjątkowo w szkole, w której wprost wychwalano cnoty całych familii. Należy pamiętać, że staropolskie szkolnictwo opierało się na fundacjach możnych, a te oczywiście uzależnione były w pewnym stopniu od zabiegów szkoły. Wymownego przykładu dostarczają dwa panegiryki, napisane na cześć wspomnianego wyżej Andrzeja Działyńskiego, zwłaszcza, że w tym czasie nauki pobierali

20 Triumphus Virtutum, Praeeuntibus Divis tutelaribus, Ecclesiae Posnaniensis, In felicem Adventum [...] Ioannis Węzyk [...], Posnaniae 1624Trf. A2.

21 J.C. Sewerynowicz, Imperator igeniorum ..., Posnaniae 1742, f. a i n.

22 Idem, Vicarius in spiritualibus..., Posnaniae 1741, f. C2.

23 A. Rekuc, Ł. Biskupski, ELEMOZYNE Iuventutis Lubranscianae in reditu ex Italia ..., Posnaniae 1621; K.F. Jarmundowicz, Campana virtutibus..., Posnaniae 1724. 
tu także jego bracia - Józef i Aleksander, i do nich autor zwrócił się w tekście bezpośred$n^{2}{ }^{24}$. Ważnym przykładem jest też panegiryk na cześć ucznia szkoły retoryki, Kazimierza Raczyńskiego, wojewodzica poznańskiego, napisany przez rektora Akademii, Jakuba Marciszowskiego w 1756 r., przy okazji święta jego patrona - Kazimierza, „Świętego Królewica Polskiego"25. W kwestii stosunku do szlachty wielce wymowne jest, że statuty szkoły z 1746 r. zakładały możliwość uzyskania przez ucznia od dyrektora pozwolenia na noszenie broni (w treści przysięgi zapisano: ,arma non portabo, nisi mihi specialiter per Clarissimum Directorem data fuerit facultas" ${ }^{26}$ ). Niektórzy uczniowie, o czym trzeba wspomnieć, mieli zapewnione mieszkanie w bursach szkolnych - np. w ramach fundacji Rozdrażewskiego czy w bursie Szołdrskich, gdzie pozostawali pod opieką profesorów Akademii, z którymi m.in. przygotowywali się do zajęć szkolnych ${ }^{27}$. Czterej uczniowie z najbliższej rodziny Rozdrażewskiego („,de Prosapia familiae ejus”) mieli mieć zapewniony także wspólny stół z profesorami szkoły ${ }^{28}$.

Materiały źródłowe pokazują, że odpowiednie pochodzenie społeczne, ale zawsze połączone z dobrym przygotowaniem merytorycznym, było kryterium wyboru osoby reprezentującej szkołę podczas ważnych uroczystości. Zwyczajem było przygotowanie na takie okoliczności mowy, najczęściej obszernej i wygłaszanej z pamięci. Chociaż zwykle czynili to profesorowie, Akademia Lubrańskiego czasem umożliwiała także i uczniom zaprezentowanie się szerszej publiczności, wykazanie dobrą pamięcią i retorycznymi umiejętnościami. Z pewnością stanowiło to doskonałe ćwiczenie, przygotowujące przyszłych senatorów do zadań publicznych, było też dużym wyróżnieniem. Stanowiło również dla nich pierwszą okazję do zaistnienia wśród dostojnych gości, bardzo często reprezentujących najwyższe urzędy Rzeczypospolitej, o czym skrzętnie informowali historiografowie.

Jednym z ciekawszych przykładów jest wygłoszenie mowy podczas ingresu Andrzeja Szołdrskiego na biskupstwo poznańskie przez ucznia szkoły retoryki Akademii, Krzysztofa Grzymułtowskiego. Zwracał on w niej uwagę słuchaczy na dobre pochodzenie biskupa, ale przede wszystkim i wielokrotnie podkreślał liczne jego cnoty, mądrość i użyteczność dla Rzeczypospolitej ${ }^{29}$. Mowa w katedrze była też okazją do zaprezentowania aktualnej sytuacji międzynarodowej i zagrożenia dla ojczyzny, płynącego ze strony Imperium Ottomańskiego $^{30}$. Warto podkreślić wyjątkową przejrzystość stylu, jego rzeczowość i umiarkowanie w wykorzystaniu erudycyjnych kontekstów. Ranga tego wydarzenia świadczy o dużym zaufaniu, jakim musiał cieszyć się ten uczeń, zasługujący zresztą na szczególną uwagę. Jego późniejsze dokonania i ich wpływ na dzieje Rzeczypospolitej są dobrze znane, a zapowiadała je aktywność młodego Grzymułtowskiego już w latach szkolnych. Wspomina

24 M.J. Gniatkiewicz, Candor Apollinis Lubransciani..., Posnaniae 1708, f. A1, B2v i n.; por. A. Piątkowski, Niezamierzone strzały Dzialyńskich...

25 J.M. Marciszowski, Nayiasnieyszy y niezwycięzony prawem natury y łaski..., Poznań 1756.

26 Statuta Academiae Posnaniensis ex Antiquis Statutis et Ordinationibus..., [Kraków] 1746, rkps Biblioteki Jagiellońskiej [dalej BJ] 1157, f. 12.

27 Zob. M. Nowicki, Organizacja, majątek $i$ życie codzienne w Bursie Szołdrskich w Poznaniu w latach 1653-1780, „Kwartalnik Historii Kultury Materialnej”, 61/2013, nr 3, s. 391-408.

28 Academia controversa seu controversiarum Academiae Cracoviensis cum aemula Societate Iesu..., rkps BJ 227 III, f. 55; por. Acta causarum Consistorii Posnaniensis 1619-1621, Archiwum Archidiecezjalne w Poznaniu (dalej: AAP), sygn. AC 138, f. 51v.

29 K. Grzymułtowski, Echo Virtutum..., Posnaniae 1636, passim, zwłaszcza f. Aiiiv-B.

30 Ibidem, f. Biiiv i n. 
to zresztą w panegiryku późniejszy profesor retoryki w Akademii Lubrańskiego, Andrzej Stanisław Sałecki. Podkreślał szczególnie jego pobożność i posłuszeństwo wobec nauczycieli, pilność w studiowaniu sztuk wyzwolonych i bystrość rozumu w zgłębianiu nauk ${ }^{31}$. Domyślać się można, że pochodzenie społeczne, posiadane talenty i duże zaangażowanie ucznia spowodowały, że środowisko szkolne zaopiekowało się w sposób szczególny młodym Grzymułtowskim. Wiadomo np., że jeszcze jako młodzieniec, prawdopodobnie uczeń szkoły, przyglądał się sądom skarbowym, którym przewodził protektor Akademii, biskup Andrzej Szołdrski ${ }^{32}$. Jest on też autorem konkluzji filozoficznych, bronionych zapewne przez niego przed społecznością akademicką, zgodnie z panującym zwyczajem ${ }^{33}$. Z owych konkluzji wynika, że równolegle studiował on także prawo. Pokazuje to, jak gruntowne było jego kształcenie, a wiadomo przecież, że przedstawiciele szlachty nierzadko zabierali dzieci ze szkoły, gdy te tylko zapoznały się z podstawami sztuk wyzwolonych.

Często podczas publicznych uroczystości wręczano adresatowi przemówienia tomik wierszy. Przykładem jest sytuacja z 1631 r., kiedy to Jerzy Chlebowicz, kasztelanic wileński, po wygłoszonej mowie w imieniu uczniów Akademii, w obecności „Prześwietnych Panów Królestwa i Kurii”, wręczył biskupowi Adamowi Nowodworskiemu księgę gratulacyjną ${ }^{34}$. Znanych jest jeszcze kilka mów autorstwa uczniów Akademii Lubrańskiego senatorskiego pochodzenia, jak chociażby ta z 19 października 1727 r., wygłoszona w katedrze poznańskiej przez Piotra Rozdrażewskiego, ucznia szkoły retoryki Akademii, w obecności „korony tej bazyliki”, tzn. kapituły katedralnej oraz licznych „wielkich gości”"35. Zaprezentowana została ona z okazji święta Jana Kantego, chociaż jej autor nie omieszkał zadedykować jej swojemu opiekunowi, Janowi Antoniemu Rozdrażewskiemu, opatowi lubińskiemu i referendarzowi królewskiemu. Mowa ta stanowi bardzo obszerny panegiryk, zawierający liczne nawiązania do kultury antycznej i Biblii. Z okazji święta Jana Kantego uczniowie wygłaszali mowy przynajmniej jeszcze kilka razy, ale, niestety, nie zachowała się ich treść. W 1750 r. zadanie to konwokacja Akademii Lubrańskiego powierzyła Adamowi Bielińskiemu, kasztelanicowi lędzkiemu; w 1751 r. kasztelanicowi poznańskiemu Kazimierzowi Raczyńskiemu (w tym roku obecnych było pięciu senatorów, wielu innych dostojników państwowych i oczywiście członkowie kapituły katedralnej), w 1770 r. kasztelanicowi krzywińskiemu, Marcinowi Wilkowskiemu ${ }^{36}$.

Czasami powierzano uczniom zadanie wygłoszenia mowy podczas uroczystości odnowienia studiów, przypadającej tuż przed zakończeniem roku akademickiego. Pięknym tego przykładem jest utwór Piotra Gembickiego (h. Nałęcz), Towarzysza Znaku Pancernego (Cohortis Loricatae Commilito), ucznia szkoły poetyki, zaprezentowany w auli Lubranscianum 11 lipca 1767 r., w którym w wyjątkowo poetycki sposób zachęcał uczniów, by

\footnotetext{
31 A.S. Sałecki, Applavsvs academicvs..., Posnaniae 1660, f. B3-B4.

32 A.W. Jabłonowski, Krzysztofa Grzymultowskiego wojewody poznańskiego Listy i mowy, Warszawa 1876, s. VI i n.

33 K. Grzymułtowski, Disputatio tertia de ente mobili..., Posnaniae 1638.

34 Acta Capituli Posnaniensis 1624-1634, AAP, sygn. CP 51, f. 426; J. Łukaszewicz, Obraz historyczno-statystyczny miasta Poznania w dawniejszych czasach, Poznań 1998, t. 2, s. 261 podaje imię Wojciech.

35 P.E. Rozdrażewski, Declamator Verbi..., Posnaniae 1727; por. A. Goczałkowski, Thesaurus virtutum \& sapientiae..., Posnaniae 1744; B. Ślaski, In laudem B. Joannis Cantii..., Posnaniae 1765, od f. 10.

36 Liber Convocationum Inclytae Academiae Posnaniensis [...], rkps BJ 247 III, p. 2, 3, 66.
} 
po wakacyjnym odpoczynku z pozytywnym nastawieniem wracali do szkolnych trudów. Dowodził, że czas nauki jest bardzo ważny, a w razie zaniedbania - trudny do odrobienia ${ }^{37}$.

Edukacji przyszłych senatorów sprzyjały wykorzystywane w szkole in Summo Posnaniensi metody wychowawcze, przede wszystkim metody indukcyjne, stosowane w toku całego procesu dydaktycznego. Na szczególną uwagę jednak zasługuje teatr szkolny, a to ze względu na podejmowaną w nim tematykę (w dużym stopniu patriotyczno-obywatelską, częściowo moralno-religijną) oraz siłę oddziaływania na wychowanie ${ }^{38}$. W projekcie statutów szkoły z 1619 r. (ale już nie w wersji wydrukowanej w Krakowie) zapisano, że przedstawienia teatralne miały się odbywać raz do roku (,semel in anno fiant”), deklamacje natomiast co miesiąc ${ }^{39}$. Chociaż programów nie zachowało się wiele, to pozwalają one stwierdzić, że spektakle odbywały się dość regularnie i uczestniczyli w nich także przedstawiciele omawianej grupy społecznej.

By w pełni ukazać, jak wyglądało nauczanie przyszłych senatorów w Akademii Lubrańskiego, trzeba by dokładnie przeanalizować profil edukacyjny szkoły w poszczególnych okresach, na co niestety nie pozwalają ramy niniejszego opracowania. Można jednak w tym miejscu wskazać na kilka ważnych dla podjętego tu zagadnienia aspektów. Podstawą nauczania był język łaciński, którym uczniowie musieli posługiwać się w szkole i poza jej murami i to jest elementem oczywistym ówczesnej rzeczywistości szkolnej. Akademia Lubrańskiego jednak zapewniała także świetne kształcenie języka ojczystego od pocz. XVII w., co nie było częstym zjawiskiem przed poł. XVIII w. W zakresie obu języków uczono się gramatyki, ortografii, poetyki i retoryki, wraz z podstawowymi formami literackimi. Od poł. XVIII w. nauczano tu także języka francuskiego ${ }^{40}$ i niemieckiego ${ }^{41}$, co świadczy o chęci zaspokojenia szlacheckich potrzeb w tym zakresie. Pamiętać należy o funkcjonującym tu studium filozoficznym, prawniczym i teologicznym. O ile ostatnie oczywiście przeznaczone było dla duchowieństwa, to z dwóch pierwszych korzystali także młodzi magnaci (w $1624 \mathrm{r}$. dla przykładu prawa uczyli się tu Wojciech Tolibowski i Jakub Cielecki ${ }^{42}$ ). W kontekście szkoły prawniczej trzeba zaznaczyć, że miała ona praktyczny charakter, o czym dobitnie świadczą notatki szkolne Ludwika Szołdrskiego ${ }^{43}$. Młodzież zdobywała tu także wiedzę z zakresu historii, geografii, ówczesnego systemu miar i wag, arytmetyki i geometrii (nauka matematyki była na wysokim poziomie). Warto też podkreślić, że w okresie oświeceniowym pojawiły się w szkole nieśmiałe próby wprowadzenia do nauczania nowych zdobyczy nauk przyrodniczych i filozoficznych, dzięki czemu młodzież miała świadomość o ich istnieniu i mogła później indywidualnie uzupełnić swoje wykształcenie.

\footnotetext{
37 P. Gembicki, Honor y fortuna ..., Poznań 1767, f. C4v; por. J.J. Muszyński, Praeconia litterarum ..., Posnaniae 1772 .

38 Zob. M. Nowicki, Edukacyjne walory publicznych występów poznańskiej młodzieży szkolnej w XVI-XVIII wie$k u$, „Studia Edukacyjne”, 15/2011, s. 190 i n.; tam też przykłady i bibliografia.

39 Statuta Collegii Lubransciani liberalitate ac munificentia [...] restaurati ac dotati..., 1619, rkps BJ 227 III, f. 44.

40 Rationale Collegii Lubransciani Academiae Posnaniensis, rkps BJ 95, f. 85.

41 J .M. Marciszowski, Ordinatio studiorum in Collegio Lubransciano, Posnaniae 1756, f. a2.

42 Zob. Triumphus Virtutum...

43 Wydał je drukiem: J. Łukaszewicz, Historya szkół w Koronie i w Wielkiem Księstwie Litewskiem od najdawniejszych czasów aż do roku 1794, Poznań 1849, t. 1, s. 218.
} 
Ważne miejsce w kształceniu przedstawianej grupy młodzieży zajmować musiało wychowanie religijne i moralne, a obok tego nauczanie obyczajów. Jak już wyżej zauważono, szczególne możliwości w tym zakresie miała młodzież mieszkająca w bursach szkolnych, a więc w dużym stopniu właśnie pochodzenia magnackiego. Statuty szkolne z 1619 i 1746 r. normowały zachowanie w szkole, a zwłaszcza przy stole (w jakiej kolejności zajmować miejsca, jak zachowywać się podczas posiłków, o lekturze Pisma Świętego itd.), zasady posłuszeństwa nauczycielom, statuty zakazywały nocowania poza kolegium i potajemnego wychodzenia, wreszcie porządkowały kwestie uczestniczenia w życiu religijnym - w nabożeństwach, litaniach, spowiedziach ${ }^{44}$.

Powyższe uwagi prowadzą do przekonania, że Akademia Lubrańskiego posiadała dość atrakcyjną propozycję edukacyjną dla dzieci magnackich, z czego też chętnie korzystano. Program nauczania i wykorzystywane metody nauczania z pewnością sprzyjały przygotowaniu młodzieży do późniejszych obowiązków senatorskich, oczywiście z zastrzeżeniem konieczności uzupełnienia edukacji, jak to ukazano we wstępie do niniejszego opracowania. Ponadto, na co można zwrócić uwagę, profesorowie Akademii potrafili uczynić zadość magnackiej potrzebie wywyższenia. Było to w dużym stopniu związane z zabiegami o dodatkowe źródła dochodów dla siebie i swojej placówki, ale pozwalało przy okazji działać wychowawczo na mecenasów i uczniów szkoły oraz stymulować ich do realizowania w życiu wybranych wartości. W kwestii adekwatności programu nauczania do potrzeb społecznych można stwierdzić, że chociaż Akademia Lubrańskiego nie skorzystała z popularnego modelu tworzenia oświeceniowych konwiktów szlacheckich na wzór np. jezuickich ${ }^{45}$ i nie zreformowała swoich burs szkolnych, to podjęła szereg działań, mających na celu unowocześnienie programu nauczania. Dzięki temu zainteresowanie poznańską placówką nie zmalało i nadal mogła ona realizować swoją misję, przygotowując młodzież do praktyki publicznej i dla dobra państwa.

\section{Bibliografia}

Academia controversa seu controversiarum Academiae Cracoviensis cum aemula Societate Iesu in regno Poloniae de iure Universitatis Analecta, collecta opera Martini Radyminski, S.A.P., Biblioteka Jagiellońska, rkps 227 III.

Acta Capituli Posnaniensis 1624-1634, Archiwum Archidiecezjalne w Poznaniu, sygn. CP 51. Acta causarum Consistorii Posnaniensis 1619-1621, Archiwum Archidiecezjalne w Poznaniu, sygn. AC 138.

Axer J., Kultura polska z punktu widzenia mechanizmów recepcji tradycji antycznej. Prolegomena do syntezy, w: Humanistyczne modele kultury nowożytnej wobec dziedzictwa starożytnego, red. M. Prejs, Warszawa 2010, s. 15-81.

Bieńkowski T., Panegiryk a życie literackie w Polsce XVI i XVII wieku, w: Z dziejów życia literackiego w Polsce XVI i XVII w., red. H. Dziechcińska, Wrocław 1980, s. 183-196.

Cieśla M., Dzieje nauki języków obcych w zarysie, Warszawa 1974.

Czapliński W., Długosz J., Życie codzienne magnaterii polskiej w XVII wieku, Warszawa 1982.

44 Sanctiones et leges Collegii Lubransciani Nuperrime ROZRAZOVIANA liberalitate instaurati, Cracoviae 1619, f. A3v-B1; Statuta Academiae Posnaniensis, f. 12V i n.

45 Por. K. Puchowski, Jezuickie kolegia szlacheckie Rzeczypospolitej Obojga Narodów. Studium z dziejów edukacji elit, Gdańsk 2007. 
Dmitruk K., Problemy publiczności literackiej w dawnej Polsce, w: Publiczność literacka i teatralna w dawnej Polsce, red. H. Dziechcińska, Warszawa-Łódź 1985, s. 7-38.

Dunin A.F., Corona tribus caelicolis Eliae, Philippo Nerio, doctori Angelico Thomae..., Posnaniae 1755.

Dzianotti J.J., Corona triumphalis militantis ecclesiae D. Thomas Aquinas..., Posnaniae 1720.

Dzianotti J.J., Securitas ecclesiae et patriae avita ascia [...] Petri [...] Tarto..., Posnaniae 1721.

Gembicki P., Honor y fortuna Mężowi uczonemu hołduie..., Poznań 1767.

Gniatkiewicz M.J., Candor Apollinis Lubransciani post fata [...] Andream in Dzialin et Kościelec Dziatyński..., Posnaniae 1708.

Goczałkowski A., Thesaurus virtutum \& sapientiae..., Posnaniae 1744.

Górnicki Ł., Dworzanin polski, w: Źródła do dziejów wychowania i myśli pedagogicznej, t. 1, red. S. Wołoszyn, Kielce 1995, s. 255-259.

Grzymułtowski K., Disputatio tertia de ente mobili..., Posnaniae 1638.

Grzymułtowski K., Echo Virtutum Illustrissimi ac Reverendisiimi Domini, Andreae Szotdrski..., Posnaniae 1636.

Hincza H., Lubrański wskrzeszony, [Poznań] 1618.

Hincza H., Stopnie do sławy, na smierc Jaśnie Wielmożnego Pana Jego Mości Pana Pana Iana z Czarnkowa Czarnkowskiego..., Poznań 1619.

Jabłonowski A.W., Krzysztofa Grzymułtowskiego wojewody poznańskiego Listy i mowy, Warszawa 1876.

Jarmundowicz K.F., Campana virtutibus [...] D. Bonawentura..., Posnaniae 1724.

Kitowicz J., Opis obyczajów za panowania Augusta III, Warszawa 1985.

Liber Convocationum Inclytae Academiae Posnaniensis [...], Biblioteka Jagiellońska, rkps 247 III.

Lipiewicz A., Jason in Colchide Aurei Velleris [...], Posnaniae 1746.

Łukaszewicz J., Historya szkół w Koronie i w Wielkiem Księstwie Litewskiem od najdawniejszych czasów aż do roku 1794, t. 1, Poznań 1849.

Łukaszewicz J., Obraz historyczno-statystyczny miasta Poznania w dawniejszych czasach, t. 2, Poznań 1998.

Marciszowski J.M., Nayiasnieyszy y niezwycięzony prawem natury y łaski krolewic Kazimierz S...., Poznań 1756.

Marciszowski J.M., Ordinatio studiorum in Collegio Lubransciano, Posnaniae 1756.

Muszyński J.J., Praeconia litterarum Anno Scholastico recens affulgente..., Posnaniae 1772.

Nowicki M., Akademia Lubrańskiego: organizacja szkoły i działalność wychowawcza, Warszawa 2015.

Nowicki M., Edukacyjne walory publicznych występów poznańskiej młodzieży szkolnej w XVI-XVIII wieku, ,Studia Edukacyjne”, 15/2011, s. 183-195.

Nowicki M., Organizacja, majątek $i$ życie codzienne w Bursie Szołdrskich w Poznaniu w latach 1653-1780, „Kwartalnik Historii Kultury Materialnej”, 61/2013, nr 3, s. 391-408.

Ojcowskie synom przestrogi: instrukcje rodzicielskie (XVI-XVII w.), red. D. Żołądź-Strzelczyk, M.E. Kowalczyk, Wrocław 2017.

Piątkowski A., Niezamierzone strzały Działyńskich..., Poznań 1708.

Przestrogi i nauki dla dzieci: instrukcje rodzicielskie (XVIII w.), red. D. Żołądź-Strzelczyk, M.E. Kowalczyk, Wrocław 2017. 
Puchowski K., Jezuickie kolegia szlacheckie Rzeczypospolitej Obojga Narodów. Studium z dziejów edukacji elit, Gdańsk 2007.

Rationale Collegii Lubransciani Academiae Posnaniensis, Biblioteka Jagiellońska, rkps 95.

Rekuc A., Biskupski Ł., ELEMOZYNE Iuventutis Lubranscianae in reditu ex Italia..., Posnaniae 1621.

Rozdrażewski P.E., Declamator Verbi semel in aeternitate locuti [...] D. Joannes Cantius [...], Posnaniae 1727.

Sałecki A.S., Applavsvs academicvs illvstrissimo ac magnifico domino, d. Christophoro Grzymvttowski..., Posnaniae 1660.

Sanctiones et leges Collegii Lubransciani Nuperrime ROZRAZOVIANA liberalitate instaurati, Cracoviae 1619.

Sewerynowicz J.C., Imperator igeniorum, doctorum caesar [...] Thomas de Aquino..., Posnaniae 1742.

Sewerynowicz J.C., Vicarius in spiritualibus, et officialis generalis [...] per generosum vero Dnum Adalbertum Krzywosądzki, [...] Auditorem Eloquentiae..., Posnaniae 1741.

Sobieraj B., „Dla edukacyi, lub też dla dalszej professyi promocyi” - uwagi o edukacji młodzieży szlacheckiej w palestrze w XVIII wieku, w: Społeczne i kulturowe uwarunkowania edukacji Rzeczypospolitej XVI-XVIII wieku. Materiaty z badań, część pierwsza, red. K. Puchowski, wstęp i oprac. J. Orzeł, Warszawa 2017, s. 117-134.

Sobieraj B., Z problematyki nauczania prawa ojczystego i narodów w pijarskim Collegium Nobilium w Warszawie, w: Społeczne i kulturowe uwarunkowania edukacji Rzeczypospolitej XVI-XVIII wieku. Materiały z badań, część druga, red. K. Puchowski, wstęp i oprac. J. Orzeł, Warszawa 2018, s. 51-60.

Statuta Academiae Posnaniensis ex Antiquis Statutis et Ordinationibus ejusdem Academiae tum ex Punctis ab Illustrissimo Capitulo Posnaniensi recetrer transmissis. Rectoratu [...] D. M. Casimiri Pałaszowski, [Kraków] 1746, Biblioteka Jagiellońska, rkps 1157.

Statuta Collegii Lubransciani liberalitate ac munificentia [...] Joannis Rozrazewskii restaurati ac dotati [...], 1619, Biblioteka Jagiellońska, rkps 227 III.

Ślaski B., In laudem B. Joannis Cantii [...] Oratio..., Posnaniae 1765.

Triumphus Virtutum, Praeeuntibus Divis tutelaribus, Ecclesiae Posnaniensis, In felicem Adventum [...] Ioannis Węzyk [...], Posnaniae 1624.

Żołądź D., Ideaty edukacyjne doby staropolskiej. Stanowe modele i potrzeby edukacyjne szesnastego i siedemnastego wieku, Warszawa-Poznań 1990. 